\title{
ПОРУШЕННЯ ЗВ'ЯЗУВАЛЬНОЇ ФУНКЦІЇ СИРОВАТКОВОГО АЛЬБУМІНУ, БІЛКОВОГО ТА ЛІПІДНОГО ОБМІНУ І ЇХ КОРЕКЦІЯ У ХВОРИХ НА ГІПЕРТОНІЧНУ ХВОРОБУ В ПОЄДНАННІ З НЕАЛКОГОЛЬНИМ СТЕАТОГЕПАТИТОМ
}

\author{
๑С. М. Андрейчин, Ю. Р. Дзьордзьо \\ Тернопільський начіональний медичний університет імені І. Я. Горбачевського МОЗ України
}

PЕЗЮМЕ. В останні роки значно підвищився інтерес до вивчення гіпертонічної хвороби, у зв'язку з високим рівнем захворюваності на цю патологію, що призводить до тривалої втрати працездатності. Серйозність проблеми пов'язана також із низькою ефективністю лікування таких хворих. Важлива роль у перебігу цього захворювання належить різним коморбідним станам, зокрема, неалкогольному стеатогепатиту, однак патогенез такої поєднаної патології досліджений недостатньо.

Мета - дати клініко-патогенетичну оцінку порушень зв'язувальної функції сироваткового альбуміну (ЗФСА) при гіпертонічній хворобі з діастолічною серцевою недостатністю у хворих із супутнім неалкогольним стеатогепатитом (НАСГ) та запропонувати медикаментозну корекцію виявлених змін.

Матеріал і методи. Обстежено 40 хворих на гіпертонічну хворобу II-ІІІ ступенів. Їх було поділено на 2 групи. До 1 групи увійшли пацієнти з гіпертонічною хворобою без ураження печінки, до 2 - хворі із супутнім неалкогольним стеатогепатитом. Усі хворі пройшли стандартне клінічне обстеження, також у них визначали ЗФСА, білкові фракції, ліпідограму.

Результати. У пацієнтів 1 групи виявлені порушення ліпідограми (атерогенний тип дисліпідемії), при супутньому НАСГ виявлено достовірне зниження ЗФСА, а також порушення білкового та ліпідного обміну. Хворі обох груп отримували базову антигіпертензивну терапію. У другій групі додатково приймали препарат Антраль 200 мг тричі на добу впродовж 2 місяців. Після проведеного лікування у більшості хворих 2 групи мали місце достовірне збільшення ЗФСА та покращення білкових фракцій та ліпідного обміну.

Висновки. Коморбідність гіпертонічної хвороби з неалкогольним стеатогепатитом супроводжується достовірним зниженням ЗФСА та більш глибокими змінами в білковому та ліпідному обміні. Додаткове призначення Антралю таким хворим проявляється істотним збільшенням ЗФСА та нормалізацією білкового та ліпідного обміну.

КЛючОВІ СлОВА: гіпертонічна хвороба; неалкогольний стеатогепатит; зв'язувальна функція сироваткового альбуміну; Антраль, білковий обмін; ліпідний обмін.

Вступ. Незважаючи на те, що останнім часом досягнуто значних успіхів у діагностиці та лікуванні гіпертонічної хвороби, вона залишається серйозною проблемою охорони здоров'я в Україні та світі.

Вона викликає вторинне ураження різних органів і систем, а також сприяє виникненню багатьох захворювань. На артеріальну гіпертензію хворіють 30-45 \% дорослого населення країн світу, в Україні цей показник становить 30 \%. Значна роль у перебігу цього захворювання належить різним коморбідним станам, які ускладнюють його діагностику та лікування.

Артеріальна гіпертензія часто поєднується із захворюваннями печінки, а саме НАСГ. Найменш вивченою ланкою патології печінки $\epsilon$ порушення її альбуміносинтезувальної функції.

Альбумін становить основну частину білків плазми крові й виконує важливі функції в організмі. До них належить здатність зв'язувати велику кількість амфіфільних низькомолекулярних речовин - білірубін, жирні кислоти, інші метаболіти, токсини і ксенобіотики (в тому числі лікарські речовини) і перенесення їх до органів детоксикації та біотрансформації, що $\epsilon$, без сумніву, важливим фактором у забезпеченні гомеостазу, особливо в умовах патології [8]. Порушення цієї функції призводить до накопичення токсичних компонентів i, як наслідок, до вторинного ураження органів, зокрема печінки.

Вивчення впливу гіпертонічної хвороби з діастолічною серцевою недостатністю в поєднанні 3 НАСГ на зв'язувальну здатність сироваткового альбуміну дозволить зрозуміти, як коригувати ці процеси та мінімізувати згубний вплив на організм порушення функції альбуміну.

Матеріал і методи дослідження. Нами було обстежено 40 хворих на гіпертонічну хворобу II стадії з 2-3 ступенем артеріальної гіпертензії у поєднанні з діастолічною серцевою недостатністю I - III ФК за NYHA, серед них 16 чоловіків (40\%) та 24 жінки (60\%). Вік пацієнтів склав 35-76 років. Хворих було поділено на 2 групи. До 1 групи увійшли 15 осіб з ГХ без супутньої патології, до 2 групи - 25 осіб із супутнім НАСГ. У 8 пацієнтів встановлено CH I ФК (NYHA), у 17 - CH II ФК (NYHA), і в 15 - III ФK (NYHA).

Тривалість гіпертонічної хвороби в хворих становила від 6 до 25 років. У 29 хворих діагностовано АГ 2 ст. і у 11-АГ 3 ст. У дослідження не вклю- 
Огляди літератури, оригінальні дослідження, погляд на проблему, випадок з практики, короткі повідомлення чались пацієнти з симптоматичною гіпертензією, особи що вживають алкоголь (понад 40 мл етанолу на тиждень для чоловіків і 20 мл для жінок), а також хворі, що мали на момент огляду або в анамнезі дані за вірусні, медикаментозні та аутоімунні гепатити.

В осіб без супутнього ураження печінки переважав низький та помірний кардіоваскулярний ризик (КВР), у 2 групі осіб - високий та дуже високий KBP.

Усі пацієнти мали встановлений діагноз та отримували лікування згідно з критеріями уніфікованого протоколу надання медичної допомоги хворим на артеріальну гіпертензію МОЗ України (наказ МО3 від 24.05.2012 року № 384) [4], крім того 25 пацієнтів із НАСГ у 2 групі додатково отримували лікування гепатопротектором згідно з наказом МО3 (від 06.11.2014 № 826) [5]. Контрольна група складала 25 практично здорових осіб, в тому числі 11 чоловіків і 14 жінок аналогічного віку.

Функціональний стан печінки досліджували за допомогою соноеластографії на апараті Ultima SM-30 методом SWEI з визначенням жорсткості паренхіми печінки (ЖПП), яка становила в середньому 8,42 кПА у хворих із НАСГ.

Усім обстежуваним визначали ЗФСА за методом С. І. Чагера (1975 р.) [12].

Біохімічними методами у сироватці крові визначали загальний білок, альбумін, глобуліни, альбуміно-глобуліновий коефіцієнт, загальний холестерин, лПнЩ, лПВЩ, загальні ліпіди, тригліцериди [13].

Статистичний аналіз результатів проводили за допомогою пакета програм Statistica 10 та Microsoft Excel. Вираховували середнє арифметичне значення (M) та його похибку (m). Достовірність змін середніх величин результатів дослідження між групами визначали за критерієм Манна-Уїтні. При проведенні статистичної обробки використовували коефіцієнт кореляції Пірсона.

Результати й обговорення. Проведено аналіз лабораторних показників ЗФСА та білкових фракцій і ліпідного обміну у хворих на ГХ без ураження печінки та з її ураженням. Як видно з таблиці 1, ЗФСА, білкові фракції у хворих 1 групи не відрізнялися від показників контрольної групи. Водночас мали місце зміни ліпідних фракцій: збільшення рівня холестерину, лПнЩ, загальних ліпідів і тригліцеридів, відповідно на 25,04 \% (р<0,001), 42,2 \% $(p<0,001), 28,9 \%(p<0,001), 28,2 \%(p<0,001)$.

Таблиця 1. Динаміка біохімічних показників у хворих на гіпертонічну хворобу в поєднанні з НАСГ

\begin{tabular}{|c|c|c|c|c|c|c|c|c|}
\hline Показник & $\begin{array}{c}\text { Контрольна } \\
\text { група }\end{array}$ & $\mathrm{P}_{1}$ & $\begin{array}{c}\text { Група } 1 \\
(n=15)\end{array}$ & $\mathrm{P}_{2}$ & $\begin{array}{c}\text { Група } 2 \\
(n=25) \\
\text { до корекції }\end{array}$ & $P_{3}$ & $\begin{array}{c}\text { Група } 2 \\
(\mathrm{n}=25) \\
\text { після } \\
\text { корекції }\end{array}$ & $\mathrm{P}_{4}$ \\
\hline ЗФСА, г/л & $48,44 \pm 1,329$ & $>0,05$ & $45,91 \pm 1,073$ & $<0,01$ & $41,66 \pm 1,288$ & $<0,05$ & $45,29 \pm 0,939$ & $>0,05$ \\
\hline Альбумін, г/л & $59,14 \pm 1,026$ & $>0,05$ & $56,25 \pm 1,365$ & $<0,001$ & $51,96 \pm 0,659$ & $<0,001$ & $56,46 \pm 0,866$ & $>0,05$ \\
\hline Загальний білок, г/л & $74,4 \pm 0,877$ & $>0,05$ & $72,16 \pm 1,119$ & $<0,001$ & $67,69 \pm 0,781$ & $>0,05$ & $71,25 \pm 1,34$ & $>0,05$ \\
\hline Глобуліни, г/л & $39,68 \pm 1,237$ & $>0,05$ & $38,86 \pm 0,668$ & $<0,05$ & $44,21 \pm 0,798$ & $>0,05$ & $41,63 \pm 0,999$ & $>0,05$ \\
\hline $\begin{array}{l}\text { Альбуміно-глобулі- } \\
\text { новий коефіцієнт }\end{array}$ & $1,52 \pm 0,05$ & $>0,05$ & $1,45 \pm 0,039$ & $<0,001$ & $1,18 \pm 0,028$ & $<0,01$ & $1,36 \pm 0,044$ & $>0,05$ \\
\hline Холестерин, ммоль/л & $4,61 \pm 0,116$ & $<0,001$ & $6,15 \pm 0,236$ & $<0,001$ & $6,91 \pm 0,163$ & $>0,05$ & $6,47 \pm 0,096$ & $<0,001$ \\
\hline лПВЩ, ммоль/л & $1,35 \pm 0,04$ & $>0,05$ & $1,27 \pm 0,037$ & $<0,001$ & $1,06 \pm 0,051$ & $<0,05$ & $1,21 \pm 0,032$ & $>0,05$ \\
\hline ЛПнЩ, ммоль/л & $2,52 \pm 0,066$ & $<0,001$ & $4,36 \pm 0,162$ & $<0,001$ & $5,08 \pm 0,095$ & $<0,001$ & $4,37 \pm 0,081$ & $<0,001$ \\
\hline $\begin{array}{l}\text { Загальні ліпіди, } \\
\text { ммоль/л }\end{array}$ & $5,11 \pm 0,097$ & $<0,001$ & $7,19 \pm 0,095$ & $<0,001$ & $7,26 \pm 0,096$ & $>0,05$ & $7,24 \pm 0,092$ & $<0,001$ \\
\hline Тригліцериди, ммоль/л & $1,55 \pm 0,046$ & $<0,001$ & $2,16 \pm 0,105$ & $<0,001$ & $2,4 \pm 0,071$ & $<0,05$ & $2,16 \pm 0,06$ & $<0,001$ \\
\hline
\end{tabular}

\section{Примітки:}

$\mathrm{p}_{1}$ - достовірність різниці між показниками 1 та контрольної груп;

$\mathrm{p}_{2}$ - достовірність різниці між показниками 1 та 2 груп до корекції;

$\mathrm{P}_{3}$ - достовірність різниці між показниками 2 групи до корекції та 2 групи після корекції;

$\mathrm{P}_{4}$ - достовірність різниці між показниками 2 групи після корекції та контрольної групи.

В осіб з гіпертонічною хворобою та супутнім НАСГ ЗФСА статистично достовірно знизилась, порівняно $з$ контрольною групою, на $14 \%$ $(p<0,01)$. Крім того, мало місце порушення білковосинтезувальної функції печінки, про що свідчить зниження концентрації загального білка на $9,1 \%$ ( $p<0,001)$, альбуміну на 12,2 \% ( $<<0,001)$, а також збільшення фракції глобулінів на $11,4 \%$ $(p<0,05)$. Альбуміно-глобуліновий коефіцієнт був знижений на $22,6 \%(p<0,001)$, порівняно зі здоровими людьми.

Концентрація лПнщ у сироватці крові була збільшена на 101 \% порівняно з контрольною групою ( $<<0,001)$, загального холестерину, ліпідів та 
Огляди літератури, оригінальні дослідження, погляд на проблему, випадок з практики, короткі повідомлення тригліцеридів на 49,8\% ( $<<0,001), 41,9 \%$ ( $p<0,001)$, $54,7$ \% ( $><0,001)$ відповідно. Концентрація лПнщ була знижена на 22,9\% ( $p<0,001)$.

У пацієнтів із супутнім НАСГ застосування стандартного лікування в поєднанні з препаратом Антраль привело до суттєвого підвищення ЗФСА на $8,1 \%(p<0,05)$, також зросла концентрація альбуміну в сироватці крові на 8 \% ( $<<0,01)$, альбуміно-глобуліновий коефіцієнт збільшився на 14 \% $(p<0,01)$.

Суттєвими також були зміни ліпідного обміну, зокрема, знизилися рівні лПнЩ та тригліцеридів відповідно на 16,1 \% (р<0,001), 10 \% ( $<<0,01)$, крім того, зменшився й рівень загального холестерину, проте незначно - на 6,3% (р>0,05), тоді як концентрація ЛПВЩ, навпаки, збільшилася на 13,9 \% $(p<0,01)$.

Отримані результати можуть свідчити про ознаки зменшення транспортної здатності альбуміну в хворих із супутнім НАСГ, найімовірніше внаслідок ушкодження функції печінки на фоні метаболічних змін, викликаних даним захворюванням, та її відновлення на фоні прийому препарату.

Така дія Антралю на печінку пояснюється його здатністю підвищувати синтез білка і фосфоліпідів, а також знижувати проникність клітинних мембран, зменшуючи ступінь ураження компонентів ядра гепатоцитів та клітин Купфера, що, як наслідок, стимулює процеси відновлення тканини печінки [14].

Також, як видно з результатів, і в 1 і 2 групах до корекції спостерігались відмінності в ліпідному обміні, порівняно з контрольною групою, зокрема, значне збільшення ЛПнЩ та зниження лПВЩ, що свідчить про атерогенний характер дисліпідемії.

Після лікування препаратом Антраль у 2 групі відбулись досить суттєві зміни в ліпідограмі, що

\section{ЛІТЕРАТУРА}

1. Андрейчин С. М. Вплив глутаргіну на зв'язувальну функцію сироваткового альбуміну та інші показники функціонального стану печінки при гострому токсичному гідразиновому гепатиті / С. М. Андрейчин, 3. С. Скірак // Медична та клінічна хімія. - 2014. - Т. 16, № 4. - С. 66-69.

2. Скірак 3. С. Вплив препарату глутаргін на біохімічні показники при гострому алкогольному гепатиті в умовах експерименту / 3. С. Скірак // Науковий вісник Ужгородського університету. Сер. : Медицина. - 2010. Вип. 38. - С. 92-94.

3. Скірак 3. С. Показники ендогенної інтоксикації та ліпопероксидації в динаміці гострого токсичного тетрахлорметанового гепатиту / 3. С. Скірак // Інфекційні хвороби. - 2014. - № 3. - С. 89-92.

4. Про затвердження та впровадження медикотехнологічних документів зі стандартизації медичної допомоги при артеріальній гіпертензії : наказ МО3 України № 384 від 24.05.2012 року.

5. Про затвердження та впровадження медикотехнологічних документів зі стандартизації медичної допомоги при хронічних неінфекційних гепатитах : наказ МОЗ України № 826 від 06.11.2014

6. Лашкул 3. В. Особливості епідеміології артеріальної гіпертензії та ії ускладнень на регіональному рівні з 1999 по 2013 роки / 3. В. Лашкул // Сучасні медичні технології. - 2014. - № 2. - 134 с.

7. Гребеник М.В.Особливості корекції діастолічної дисфункції лівого шлуночка у хворих на гіпертонічну 
Огляди літератури, оригінальні дослідження, погляд на проблему, випадок з практики, короткі повідомлення хворобу з гіперурикемією / М.В.Гребеник, О. І. Коцюба // Ліки України. - 2016. - № 3 (199). - 72 с.

8. Видиборець С. В. Альбумін: спектр можливостей застосування / С. В. Видиборець // Семейная медицина. - 2018. - № 2 (76). - 109 с.

9. Кірієнко В. Т. Ефективність Антралю у хворих на хронічний гепатит С / В. Т. Кірієнко, В. В. Потій // Вісник наукових досліджень. - 2015. - № 3. - С. 28-30.

10. Hypertension Canada's 2017 Guidelines for Diagnosis, Risk Assessment, Prevention, and Treatment of Hypertension in Adults / A. A. Leung, S.S. Daskalopoulou, K. Dasgupta [et al.] // Can. J. Cardiol. - 2017. - Vol. 33(5). - P. 557-576.

11. Lago R. M. Diabetes and hypertension / R. M. Lago, P. P. Singh, R. W. Nesto // Nat. Clin. Pract. Endocrinol. Metab. - 2007. - Vol. 3 (10). - P. 667.

12. Чегер С. И. Транспортная функция сывороточного альбумина / С. И. Чегер. - Бухарест: Академия Румынии, 1975. - 184 с.

\section{REFERENCES}

1. Andreychyn, S.M., \& Skirak, Z.S. (2014). Vplyv hlutarhinu na zviazuvalnu funktsiiu syrovatkovoho albuminu ta inshi pokaznyky funktsionalnoho stanu pechinky pry hostromu toksychnomu hidrazynovomu hepatyti [Effect of glutargin on serum albumin binding function and other indicators of liver functional status in acute toxic hydrazine hepatitis]. Medychna ta klinichna khimiia-Medical and Clinical Chemistry, 16, 4, 66-69 [in Ukrainian].

2. Skirak, Z.S. (2010). Vplyv preparatu hlutarhin na biokhimichni pokaznyky pry hostromu alkoholnomu hepatyti v umovakh eksperymentu [Effect of glutargine on biochemical parameters in acute alcoholic hepatitis in experimental conditions]. Naukovyi visnyk Uzhhorodskoho universytetu. Ser.: Medytsyna - Scientific Bulletin of Uzhhorod University. Ser.: Medicine, 38, 92-94 [in Ukrainian].

3. Skirak, Z.S. (2014). Pokaznyky endohennoi intoksykatsii ta lipoperoksydatsii v dynamitsi hostroho toksychnoho tetrakhlormetanovoho hepatytu [Indicators of endogenous intoxication and lipoperoxidation in the dynamics of acute toxic tetrachloromethane hepatitis]. Infektsiini khvoroby - Infectious Diseases, 3, 89-92 [in Ukrainian].

4. Nakaz MOZ Ukrainy № 384 vid 24.05.2012 roku "Pro zatverdzhennia ta vprovadzhennia medykotekhnolohichnykh dokumentiv zi standartyzatsii medychnoi dopomohy pry arterialnii hipertenzii" [Order of the Ministry of Health of Ukraine No. 384 of May 24, 2012 "On approval and implementation of medical-technological documents on standardization of medical care for arterial hypertension"]. [in Ukrainian].

5. Nakaz MOZ Ukrainy № 826 vid 06.11.2014 "Pro zatverdzhennia ta vprovadzhennia medyko-tekhnolohichnykh dokumentiv zi standartyzatsii medychnoi dopomohy pry khronichnykh neinfektsiinykh hepatytakh" [Order of the Ministry of Health of Ukraine No. 826 of 06.11.2014 "On approval and introduction of medical-technological documents on standardization of medical care in chronic non-communicable hepatitis"]. [in Ukrainian].

6. Lashkul, Z.V. (2014). Osoblyvosti epidemiolohii агterialnoi hipertenzii ta yii uskladnen na rehionalnomu rivni z 1999 po 2013 roky [Features of epidemiology of arterial hypertension and its complications at the regional level

from 1999 to 2013]. Suchasni medychni tekhnolohii - Modern Medical Technologies, 2, 134 [in Ukrainian].

7. Hrebenyk, M.V., \& Kotsiuba, O.I. (2016). Osoblyvosti korektsii diastolichnoi dysfunktsii livoho shlunochka u khvorykh na hipertonichnu khvorobu z hiperurykemiieiu [Features of correction of diastolic left ventricular dysfunction in patients with hypertension with hyperuricemia]. Liky Ukrainy - Medicines of Ukraine, 3 (199), 72 [in Ukrainian].

8. Vydyborets, S.V. (2018). Albumin: spektr mozhlyvostei zastosuvannia [Albumin: a spectrum of possibilities of application]. Semeynaya medytsyna - Family Medicine, 2 (76), 109 [in Ukrainian].

9. Kiriyenko, V.T., \& Potii, V.V. (2015). Efektyvnist Antraliu u khvorykh na khronichnyi hepatyt C [Efficiency of Antral in patients with chronic hepatitis C]. Visnyk naukovykh doslidzhen - Bulletin of Scientific Researches, 3, 2830 [in Ukrainian].

10. Leung, A.A., Daskalopoulou, S.S., Dasgupta, K., McBrien, K., Butalia, S., Zarnke, K.B., ..., \& Rabi, D.M. (2017). Hypertension Canada's 2017 Guidelines for Diagnosis, Risk Assessment, Prevention, and Treatment of Hypertension in Adults. Can. J. Cardiol., 33 (5), 557-576.

11. Lago, R.M., Singh, P.P., \& Nesto, R.W. (2007). Diabetes and hypertension. Nat. Clin. Pract. Endocrinol. Metab., 3 (10), 667.

12. Cheger, S.I. (1975). Transportnaya funktsiya syvorotochnogo albumina [Transport function of serum albumin]. Izdatelstvo: Bukharest: Akademiya Rumynii [in Russian].

13. Zhulkevich, I.V., \& Vainshtein, S.G. (1986). Algorithm for phenotyping hyperlipoproteinemias and its application to the" Elektronika BZ-21" microcalculator. Laboratornoe delo, 10, 623-625.

14. Zvyagintseva, T.D., \& Chernobay, A.I. (2016). Primeneniye preparata Antral v lechenii nealkogolnogo steatogepatita: nastoyashcheye i budushcheye [Application of the drug Antral in the treatment of non-alcoholic steatohepatitis: present and future]. Chelovek i lekarstvoMan and Medicine, 17 (78), 84 [in Russian]. 
Огляди літератури, оригінальні дослідження, погляд на проблему, випадок з практики, короткі повідомлення

15. Babak, O.Ya., Fadeyenko, G.D., \& Kolesnikova, Ye.V. (2010). Opyt primeneniya preparata Antral v sostave kompleksnoy terapii nealkogolnoy zhirovoy bolezni pecheni [Experience with the use of the drug Antral as a part of complex therapy of non-alcoholic fatty liver disease]. Consilium Medicum Ukraina, 4, 5, 22 [in Russian].
16. Samohalska, O.Ye. (2009). Efektyvnist preparatu "Antral" pry nealkoholnii zhyrovii khvorobi pechinky [Efficiency of the drug "Antral" in non-alcoholic fatty liver disease]. Suchasna hastroenterolohiia - Modern Gastroenterology, 5 (49), 85 [in Ukrainian].

\title{
НАРУШЕНИЯ СВЯЗЫВАЮЩЕЙ ФУНКЦИИ СЫВОРОТОЧНОГО АЛЬБУМИНА, БЕЛКОВОГО И ЛИПИДНОГО ОБМЕНА И ИХ КОРРЕКЦИЯ У БОЛЬНЫХ ГИПЕРТОНИЧЕСКОЙ БОЛЕЗНЬЮ В СОЧЕТАНИИ С НЕАЛКОГОЛЬНЫМ СТЕАТОГЕПАТИТОМ
}

\author{
๑С. М. Андрейчин, Ю. Р. Дзьордзьо
}

Тернопольский национальный медицинский университет имени И. Я. Горбачевского МОз Украины

РЕЗЮМЕ. В последние годы значительно повысился интерес к изучению гипертонической болезни, в связи с высоким уровнем заболеваемости этой патологией, которая приводит к длительной потере работоспособности. Серьезность проблемы связана также с низкой эффективностью лечения таких больных. Важная роль в течении данного заболевания принадлежит различным коморбидным состояниям, в частности неалкогольному стеатогепатиту, однако патогенез такой совмещенной патологии исследован недостаточно.

Цель - дать клинико-патогенетическую оценку нарушений связывающей функции сывороточного альбумина (СФСА) при гипертонической болезни с диастолической сердечной недостаточностью у больных сопутствующим неалкогольным стеатогепатитом (НАСГ) и предложить медикаментозную коррекцию выявленных изменений.

Материал и методы. Обследовано 40 лиц с гипертонической болезнью II-ІІІ степени. Они были поделены на 2 группы. В 1 вошли пациенты с гипертонической болезнью без поражения печени, во 2 - больные с сопутствующим неалкогольным стеатогепатитом. Все больные прошли стандартное клиническое обследование, а также у них исследовали СФСА, белковые фракции, липидограмму.

Результаты. У пациентов 1 группы выявлено нарушение липидограммы (атерогенный тип дислипидемии), при сопутствующем НАСГ выявлено достоверное снижение СФСА, а также нарушение белкового и липидного обмена. Больные обеих групп получали базовую антигипертензивную терапию. Во второй - дополнительно принимали препарат Антраль 200 мг трижды в сутки длительностью 2 месяца. После проведенного лечения у большинства больных 2 группы имели место достоверное увеличение СФСА и улучшение белковых фракций и липидного обмена.

Выводы. Коморбидность гипертонической болезни с неалкогольным стеатогепатитом сопровождается достоверным снижением СФСА и более глубокими изменениями белкового и липидного обмена. Дополнительное назначение Антраля таким больным проявляется существенным увеличением СФСА и нормализацией белкового и липидНого обмена.

КЛЮЧЕВЫЕ СЛОВА: гипертоническая болезнь; неалкогольный стеатогепатит; связывающая функция сывороточного альбумина; Антраль; белковый обмен; липидный обмен.

\section{SERUM ALBUMIN BINDING DISORDERS, PROTEIN AND LIPID METABOLISM AND ITS MANAGEMENT IN PATIENTS WITH ARTERIAL HYPERTENSION, COMBINED WITH NON-ALCOHOLIC STEATOHEPATITIS}

\section{Horbachevsky Ternopil National Medical University}

SUMMARY. The last years showed the increased interest towards studying of arterial hypertension, due to the high rate of its pathology, which leads to a long-term loss of work ability. Importance of this problem is related as well with a low effectiveness of treatment of such patients. The important role in processing of this impairment belongs to different comorbid conditions, in particular nonalcoholic steatohepatitis (NASH), however pathogenesis of such combination is not yet enough researched.

The aim of the study - to suggest clinical, pathogenetic evaluation of disorders of serum albumin binding (DSAB) at hypertension with diastolic heart failure in patients with combined nonalcoholic steatohepatitis and offer a medication correction of presented changes. 
Огляди літератури, оригінальні дослідження, погляд на проблему, випадок з практики, короткі повідомлення

Material and Methods. 40 volunteers with hypertension of stage II-III were divided into 2 groups. Group 1 contained patients with hypertension without a liver impairment, group 2 had those with combined non-alcoholic steatohepatitis. All patients were examined with a standard clinical examination, additionally they were examined their serum albumin binding function, protein fractions and lipidogram.

Results and Discussion. In patients of group 1 it was found a lipidogram disorder (atherogenic dyslipidemia), during a concomitant NASH credible decrease DSAB, as well as impairment of protein and lipid metabolism. The patients of both groups were receiving a basic antihypertensive therapy. Group 2 additionally received medication Antral $200 \mathrm{mg}$ 3 times a day during 2 months. After conducted treatment there were found a credible increase of DSAB and improvement of protein fractions and lipid metabolism.

Conclusion. Comorbidity of arterial hypertension with non-alcoholic steatohepatitis is accompanied by a credible increase of DSAB and more profound changes in the protein and lipid metabolisms. Additional prescription of antral for such patients results in a significant increase of DSAB and normalization of protein and lipid metabolism.

KEY WORDS: arterial hypertension; non-alcoholic steatohepatitis; Serum albumin binding function; Antral; protein metabolism; lipid metabolism.

Отримано 22.01.2020 